Article

\title{
Estimation of Energy and Emissions Properties of Waste from Various Species of Mint in the Herbal Products Industry
}

\author{
Grzegorz Maj ${ }^{1}$, Agnieszka Najda ${ }^{2, *}$,, Kamila Klimek $^{3}$ and Sebastian Balant ${ }^{2}$ \\ 1 Department of Power Engineering and Transportation, University of Life Sciences in Lublin, Gleboka 28, \\ 20-612 Lublin, Poland; grzegorz.maj@up.lublin.pl \\ 2 Department of Vegetable Crops and Medicinal Plants, University of Life Sciences in Lublin, Akademicka 15, \\ 20-920 Lublin, Poland; sebastianbalant@o2.p1 \\ 3 Department of Applied Mathematics and Computer Science, University of Life Sciences in Lublin, \\ Gleboka 28, 20-612 Lublin, Poland; kamila.klimek@up.lublin.pl \\ * Correspondence: agnieszka.najda@up.lublin.pl; Tel.: +48-81-445-65-48
}

Received: 24 October 2019; Accepted: 18 December 2019; Published: 20 December 2019

\begin{abstract}
The paper presents the results of research on the physicochemical properties of plant biomass consisting of four mint species, these being Mentha $\times$ piperita L. var. citrata Ehrh._'Bergamot', Mentha $\times$ rotundifolia L., Mentha spicata L., and Mentha crispa L. The research conducted consisted of the technical analysis of biofuels-determining the heat of combustion and the calorific value of the material under study, and the content of ash, volatile compounds, and humidity. In addition, elemental analysis was carried out for the biomass under study by determining the content of carbon, hydrogen, nitrogen, and sulfur. The research demonstrated that Mentha $\times$ piperita L. var. citrata Ehrh.- 'Bergamot' had the highest energy potential with a gross calorific value of $16.96 \mathrm{MJ} \cdot \mathrm{kg}^{-1}$, and a net calorific value of $15.60 \mathrm{MJ} \cdot \mathrm{kg}^{-1}$. Among the tested materials, Mentha $\times$ rotundifolia L. had the lowest content of ash at $7.23 \%$, nitrogen at $0.23 \%$, and sulfur at $0.03 \%$, and at the same time had the highest content of volatile fraction at $70.36 \%$. When compared to hard coal, the estimated emission factors indicated a $\mathrm{CO}$ reduction of $29-32 \%, \mathrm{CO}_{2}$ reduction of $28-31 \%, \mathrm{NO}_{\mathrm{x}}$ reduction of $40-80 \%, \mathrm{SO}_{2}$ reduction of $92-98 \%$, and dust reduction of $45-61 \%$, depending on the type of biomass used.
\end{abstract}

Keywords: biomass; emission factors; energy; environmental and mechanical engineering; herbs; mint

\section{Introduction}

Direct biomass combustion requires the application of appropriate technical solutions in its installation, adapted to combusting fuels with a high proportion of volatile fractions. The market of low-power (from several $\mathrm{kW}$ to $2 \mathrm{MW}$ ) heating plants fueled with biomass offers many innovative technical solutions. Replacing coal with biomass fuel is beneficial in that it contributes to reducing gas emissions [1]; is an excellent solution for the socio-economic development of disadvantaged areas, rural or peripheral [2]; and has the possibility of being implemented at a large scale [3]. In terms of energy yield, 2 tonnes of biomass is on average an equivalent to 1 tonne of hard coal. At the local level and especially in low-power heating plants, the most noticeable negative effect of combusting coal is the emission of dust and organic pollutants [4], including polycyclic aromatic hydrocarbons (PAHs) [5] and particulate matter PM [6]. Biomass is considered as a renewable fuel, neutral in terms of $\mathrm{CO}_{2}$ emissions [7], and burning biomass in heating boilers, including coal boilers, can effectively reduce emissions [8] and lead to the diversification of energy sources by replacing fossil fuels with biofuels [9].

Biomass, as a renewable energy source, has many advantages, which encourage its use as an energy source. Its environmental advantages include broadly understood environmental protection-reduction 
of harmful gas and dust emissions $\left(\mathrm{CO}_{2}, \mathrm{NO}, \mathrm{SO}_{2}\right)[10]$, and reduction of mineral extraction and thus curbing environmental degradation caused by uncontrolled decomposition of unused biomass [11,12].

One of the basic goals of a low-emissions economy is to reduce the flow of biodegradable waste mass within certain time limits. Reaching this objective will not be possible without the implementation and development of installations for the thermal conversion of residues from agricultural and agriculture-related production, especially in systems for managing residues in the herbal product industry [13]. Installations for the conversion of residues from the sector of agricultural, horticultural, and herbal production should ensure the possibility of fulfilling the adopted obligations to reduce biodegradable waste, and secondly, they should provide significant amounts of electricity and heat, mainly treated as energy from renewable sources $[14,15]$. In addition, it is still important to search for new, alternative energy sources characterized by low emission levels, including, apart from greenhouse gases, low dust emission [16,17]. Due to the growth of the herbal production sector, one can observe high potential for energy generation in the residues from herb production and, more importantly, in residues that cannot be offered on the consumer market.

Poland is considered as a country with great capabilities in both the production of high-quality herbal raw materials and herbal processing. This is due to the fact that over the last decade the number of farms growing herbs in Poland has increased from 18,000 to 30,000, and plantations of herbs now cover an area of over 30,000 ha, whereas in the countries of the entire European Union, the area of herbal plant cultivation covers about 80,000 ha. It is estimated that among the types of herbs, the share of mint on the global spice and herb market is $21.9 \%$ [18,19]. Modern specialized farms involved in the cultivation of herbs run plantations of specific herbaceous plant species over an area of more than 20 hectares [20,21]. In addition to the obtained raw material for a specific purpose, herbal production also generates waste [22,23]. A large amount of waste biomass is created in the place of production during harvesting, pre-processing, drying, collecting of the harvested crops, as well as in the facilities processing herbal raw materials. This indicates the possibility of managing the biomass in question for energy generation purposes, which would allow for avoidance of burning it in the fields. This frequent practice causes enormous damage to the natural environment [24,25]. Another equally important reason is the frequent practice of using leftover shredded stems for herbal products, these being tea bags and herbal blends, which causes products to be put on the market that are of low value and are enticing with a low price. Hence, the growing popularity of plant products, including herbs, translates into the interest of growers, producers, and consumers in obtaining raw material of the best quality [22], whereas products of low value for consumption could be utilised for energy purposes. Food of plant origin, despite its high nutritional value, is not really durable. Therefore, in order to preserve the natural nutritional properties conditioned by an appropriate chemical composition of the herbal raw material, it is necessary to use effective methods of its preservation immediately after harvesting, which ensures that active bodies are kept constant and that the raw material is stored safely without losses $[24,26]$. It should be noted that drying is the most popular way of preserving raw plant materials. In order to obtain raw material of satisfactory quality, thermal drying in drying plants is recommended. Currently, the most popular method of drying herbs and other plant materials on an industrial scale is convection drying [27] in chamber dryers, where solid fuels based on herbal cultivation residues can also be burnt and constitute an additional energy carrier. The use of waste biomass from the production and processing of herbal raw materials in such dryers would reduce the costs of such process.

The aim of the paper was to assess the energy potential of residues from the production of herbs in the form of stems of four mint species, including Mentha $\times$ piperita L. var. citrata Ehrh.-'Bergamot'. The yield of peppermint herb is $4-6$ tons per 1 ha per year [28,29]. Studies show that the yield of roundifolia mint is 7 to 10 tons per 1 ha per year $[19,30]$, whereas green and curly mint is $5-7$ tons per 1 ha per year $[19,31,32]$. From production, $55-60 \%$ are leaves constituting a herbal raw material and $40-45 \%[19,28,33]$ are residues in the form of dry biomass of Mentha $\times$ piperita L. var. citrata Ehrh.-'Bergamot', Mentha $\times$ rotundifolia L., Mentha spicata L., and Mentha crispa L. 


\section{Materials and Methods}

\subsection{Material}

The research covered the biomass of waste from commodity crops: Mentha $\times$ piperita L. var. citrata Ehrh.-_'Bergamot', Mentha $\times$ rotundifolia L., Mentha spicata L., and Mentha crispa L., which were obtained in 2017 and 2018 from own plantations run at the Experimental Farm Felin of the Department of Vegetable and Herb Crops in Lublin ( $51^{\circ} 25^{\prime} \mathrm{N} 22^{\circ} 56^{\prime} \mathrm{E}$ ). The harvest of the herbs was carried out during full blooming period of the plants, in accordance with the cultivation recommendations for mint. Then, the leaves from fresh shoots were picked manually in order to separate them from their stems. The obtained waste material in the form of leafless stems of four mint species was dried at $35^{\circ} \mathrm{C}$ in a convection dryer to acquire the lowest possible humidity, which was controlled during the drying process with the oven-drying method. The final water content in the material intended for research was 5.5\%. This material was selected for research due to the large acreage of crops in Poland (second largest after Chamomilla recutita and Valeriana officinalis L.) and the EU. In addition, mint is one of the best known, and most cultivated and used herbs in the world.

In order to obtain homogeneous samples for research, ca. $1 \mathrm{~kg}$ portions of each biomass type were dried.

\subsection{Experiment}

Material for laboratory analysis was in first step pulverized $(0.5 \mathrm{~mm})$ using an IKA A 11 grinder. In the research the determination of ash content (A) was measured on the basis of the EN-ISO 18122 standard [34]. The volatile matter content (V) for each type of the material was assessed according to EN-ISO 18123 [35]. For the material, the moisture content (M) was determined with EN-ISO 18134-3 [36] standard. All the analyses described above were carried out using a thermogravimetric analyzer LECO TGA 701. Determination of the gross calorific value (GCV) and net calorific value was done using EN-ISO 1928:2009 [37], with isoperibolic calorimeter LECO AC 600. In every analysis, three replicates of each biomass sample were made, and the mean value was taken for further analysis.

In this work, the fixed carbon index (FC; \%) was obtained by subtracting from $100 \%$ of the sum of $(\mathrm{M}, \mathrm{A}, \mathrm{V})$ content in percentage.

The fuel ratio index (FR) was determined, which describes the quality of fuel to compare biomass to each other as a biofuel (Equation (1)):

$$
\mathrm{FR}=\mathrm{FC} / \mathrm{V}
$$

The percentage C (carbon), H (hydrogen), N (nitrogen), and S (sulfur) content was determined according to the EN-ISO 16948:2015-07 [38] and EN-ISO 16994:2016-10 [39] standards using a Leco CHNS 628 analyzer. The oxygen content was obtained by subtracting from $100 \%$ of the sum of $(C, H$, $\mathrm{N}, \mathrm{S}$, and A) contents in percentage.

Using the factor's emission method described in detail by Borycka [40] and Maj [41], the $\mathrm{CO}, \mathrm{CO}_{2}$, $\mathrm{SO}_{2}, \mathrm{NO}_{x}$, and dust factors were determined on the basis of the ultimate analysis. The net calorific value of individual materials was used to calculate the emission factors per energy unit.

For the obtained results, the normality of distribution was checked by the Shapiro-Wilk compliance test. The impact of a tested biomass upon the value of obtained features was assessed by means of the ANOVA test. The significance differences were assessed by Tukey's HSD test (Tukey's honest significant difference test). The analysis of the principal components was performed in order to graphically visualize significant differences and similarities between the gross calorific value and the net calorific value depending on the mint species on the dendrogram. Ward's method was chosen for the grouping of the four mint species. 


\section{Results}

\subsection{Results of Proximate and Ultimate Analysis}

The gross calorific value analysis (GCV) for the examined mint species showed significant differences amongst the tested samples (Table 1). The highest gross calorific value was recorded for M. $\times$ piperita L. var. citrata Ehrh.-_'Bergamot', and was found to be a value $5.04 \%$ higher than the lowest, recorded for $M$. spicata L. The GCV difference between $M$. × piperita L. var. citrata Ehrh.-—'Bergamot' and M. $\times$ rotundifolia L. and M. crispa L. did not exceed 3.8\%. Net calorific value (NCV) for the tested mint species was in the range of $15.90-16.96 \mathrm{MJ} \cdot \mathrm{kg}^{-1} \mathrm{sm}$. However, M. spicata L. had the highest ash content, which was $70.3 \%$ higher than in the case of $M . \times$ rotundifolia $\mathrm{L}$. The analysis of volatile substances showed that the highest content of non-flammable substances was recorded in the case of $M . \times$ rotundifolia L., followed by M. crispa L., M. spicata L., and M. × piperita L. var. citrata Ehrh.--'Bergamot'. The quantification indicated that the level of volatile substances was similar in all raw materials under study and the maximum difference did not exceed $7.64 \%$. The carbon content (C) in the analyzed raw materials was at a similar level. The highest content of this element was characteristic for the stems of M. × piperita L. var. citrata Ehrh.-'Bergamot', the lowest for M. spicata L. and the difference between them was $2.05 \%$. The highest percentage of hydrogen content $(\mathrm{H})$ was recorded in the case of $M . \times$ rotundifolia L., followed by M. crispa L., and M. $\times$ piperita L. var. citrate Ehrh.-'Bergamot', and the lowest percentage was recorded in the case of M. spicata L. The difference between the highest and the lowest percentage of hydrogen content in the tested raw materials was $3.79 \%$. The highest content of nitrogen $(\mathrm{N})$ was recorded in the cases of $M$. × piperita L. var. citrata Ehrh.-'Bergamot' and M. spicata L. The lowest, most advantageous content of these elements were the stems of $M . \times$ rotundifolia L. and M. crispa L. In the case of sulphur, its highest content was observed in the material obtained from M. × piperita L. var. citrata Ehrh.-'Bergamot' and it was 83.59\% higher than the lowest content recorded for $M . \times$ rotundifolia $\mathrm{L}$.

Table 1. Results of proximate and ultimate analysis for mint.

\begin{tabular}{|c|c|c|c|c|c|}
\hline Material & $\begin{array}{l}\text { Mentha } \times \text { piperita } \text { L. var. } \\
\text { citrata } \text { Ehrh.-'Bergamot' }\end{array}$ & $\begin{array}{l}\text { Mentha } \times \\
\text { rotundifolia } \mathrm{L} \text {. }\end{array}$ & Mentha spicata $\mathrm{L}$. & Mentha crispa L. & $p$-Value \\
\hline $\mathrm{NCV} \pm \mathrm{S}_{\mathrm{x}}\left(\mathrm{MJ} \cdot \mathrm{kg}^{-1}\right)$ & $\begin{array}{c}15.60 \mathrm{D} \\
\pm 0.04\end{array}$ & $\begin{array}{c}15.24 \mathrm{C} \\
\pm 0.07\end{array}$ & $\begin{array}{l}14.82 \mathrm{~A} \\
\pm 0.06\end{array}$ & $\begin{array}{l}15.02 \mathrm{~B} \\
\pm 0.06\end{array}$ & $<0.001$ \\
\hline $\mathrm{GCV} \pm \mathrm{S}_{\mathrm{x}}\left(\mathrm{MJ} \cdot \mathrm{kg}^{-1}\right)$ & $\begin{array}{c}16.96 \mathrm{D} \\
\pm 0.05\end{array}$ & $\begin{array}{c}16.23 \mathrm{C} \\
\pm 0.07\end{array}$ & $\begin{array}{l}15.90 \mathrm{~A} \\
\pm 0.06\end{array}$ & $\begin{array}{l}16.06 \mathrm{~B} \\
\pm 0.06\end{array}$ & $<0.001$ \\
\hline $\mathrm{C} \pm \mathrm{S}_{\mathrm{x}}(\%)$ & $\begin{array}{c}47.05 \mathrm{D} \\
\pm 0.10\end{array}$ & $\begin{array}{l}45.38 \mathrm{C} \\
\pm 0.02\end{array}$ & $\begin{array}{l}44.82 \mathrm{~A} \\
\pm 0.03\end{array}$ & $\begin{array}{l}44.99 \mathrm{~B} \\
\pm 0.01\end{array}$ & $<0.001$ \\
\hline $\mathrm{H} \pm \mathrm{S}_{\mathrm{x}}(\%)$ & $\begin{array}{l}5.57 \mathrm{~A} \\
\pm 0.02\end{array}$ & $\begin{array}{l}5.76 \mathrm{C} \\
\pm 0.02\end{array}$ & $\begin{array}{l}5.54 \mathrm{~A} \\
\pm 0.02\end{array}$ & $\begin{array}{l}5.67 \mathrm{~B} \\
\pm 0.02\end{array}$ & $<0.001$ \\
\hline $\mathrm{N} \pm \mathrm{S}_{\mathrm{x}}(\%)$ & $\begin{array}{l}0.70 \mathrm{C} \\
\pm 0.01\end{array}$ & $\begin{array}{l}0.23 \mathrm{~A} \\
\pm 0.00\end{array}$ & $\begin{array}{l}0.43 \mathrm{~B} \\
\pm 0.10\end{array}$ & $\begin{array}{l}0.29 \mathrm{~A} \\
\pm 0.02\end{array}$ & $<0.001$ \\
\hline $\mathrm{S} \pm \mathrm{S}_{\mathrm{x}}(\%)$ & $\begin{array}{l}0.19 \mathrm{D} \\
\pm 0.01\end{array}$ & $\begin{array}{l}0.03 \mathrm{~A} \\
\pm 0.00\end{array}$ & $\begin{array}{l}0.14 \mathrm{C} \\
\pm 0.00\end{array}$ & $\begin{array}{l}0.07 \mathrm{~B} \\
\pm 0.00\end{array}$ & $<0.001$ \\
\hline $\mathrm{O} \pm \mathrm{S}_{\mathrm{x}}(\%)$ & $\begin{array}{l}29.14 \\
\pm 0.07\end{array}$ & $\begin{array}{l}36.09 \\
\pm 0.16\end{array}$ & $\begin{array}{l}32.85 \\
\pm 0.06\end{array}$ & $\begin{array}{l}35.27 \\
\pm 0.18\end{array}$ & $<0.001$ \\
\hline M (\%) & $\begin{array}{l}7.52 \mathrm{D} \\
\pm 0.17\end{array}$ & $\begin{array}{l}5.28 \mathrm{~A} \\
\pm 0.07\end{array}$ & $\begin{array}{l}5.94 \mathrm{C} \\
\pm 0.03\end{array}$ & $\begin{array}{l}5.58 \mathrm{~B} \\
\pm 0.02\end{array}$ & $<0.001$ \\
\hline $\mathrm{A} \pm \mathrm{S}_{\mathrm{x}}(\%)$ & $\begin{array}{l}9.83 C \\
\pm 0.06\end{array}$ & $\begin{array}{l}7.23 \mathrm{~A} \\
\pm 0.09\end{array}$ & $\begin{array}{c}10.29 \mathrm{D} \\
\pm 0.06\end{array}$ & $\begin{array}{l}8.13 \mathrm{~B} \\
\pm 0.18\end{array}$ & $<0.001$ \\
\hline $\mathrm{V} \pm \mathrm{S}_{\mathrm{x}}(\%)$ & $\begin{array}{c}64.99 \mathrm{~B} \\
\pm 0.19\end{array}$ & $\begin{array}{c}70.36 \mathrm{D} \\
\pm 0.30\end{array}$ & $\begin{array}{c}68.10 \mathrm{C} \\
\pm 0.75\end{array}$ & $\begin{array}{c}69.23 \mathrm{DC} \\
\pm 0.27\end{array}$ & $<0.001$ \\
\hline $\mathrm{FC}(\%)$ & 17.66 & 17.13 & 15.67 & 17.06 & $<0.001$ \\
\hline FR & 0.27 & 0.24 & 0.23 & 0.25 & - \\
\hline
\end{tabular}

$\mathrm{S}_{\mathrm{x}}$ : standard deviation; mean values with the same letter in a row are not significantly different for $p<0.05$ by Tukey's HSD test (Tukey's honest significant difference test). NCV: net calorific value, GCV: gross calorific value, M: moisture, A: ash, V: volatile matter content, FC: fixed carbon index, FR: fuel ratio index. 
Low levels of fixed carbon (FC) and volatile substances (V) affected the low level of fuel ratio (FR), which is typical for biofuels in the form of plant biomass. It is noteworthy that the fuel index was similar for the examined mint species, which testifies to similar technical properties of the biofuels studied.

The statistical analysis (ANOVA test) showed for all features the impact of the type of material on all tested characteristics. The Tukey HSD test showed significant differences in all characteristics studied with respect to four species of mint.

In order to obtain higher resolution and select smaller bands, we used the agglomeration approach. It was preferred and selected for interest in the lower part of the dendogram, that is, a combination of the tested mint species, as well as the gross calorific value and net calorific value (Figure 1). The dendogram shows on the $x$-axis the distance between clusters and on the $y$-axis the zone of the four individual test objects (mint species), and also GCV and NCV. In this figure, the dendogram is read from left to right. Vertical lines illustrate connected clusters. The position of the line on the scale indicates the distance at which the clusters are connected. Cluster analysis for the mint species shown generates three numbers of isolated clusters, as noted on the dendogram. The analysis of the main components performed for the gross calorific value and the net calorific value (GCV, NCV) with respect to the four species of mint indicated a division of features into three clusters on the basis of the dendrogram (Figure 1). On the basis of the conducted analysis of aggregations, it was clearly demonstrated that the gross calorific value and the net calorific value of the raw material was dependent on the mint species, which was directly related to the diversity of the chemical composition of the analyzed plant material. The first cluster gathered raw material of all mint species in relation to the net calorific value (NCV), which indicated similarity in the obtained net calorific value among these species. The second cluster consisted of raw materials M. $\times$ rotundifolia L., M. crispa L., and M. spicata L. in terms of combustion heat, whereas the third cluster created separate collections for M. × piperita L. var. citrata Ehrh.-'Bergamot', which indicated a significant difference in relation to the mint species in cluster 2.

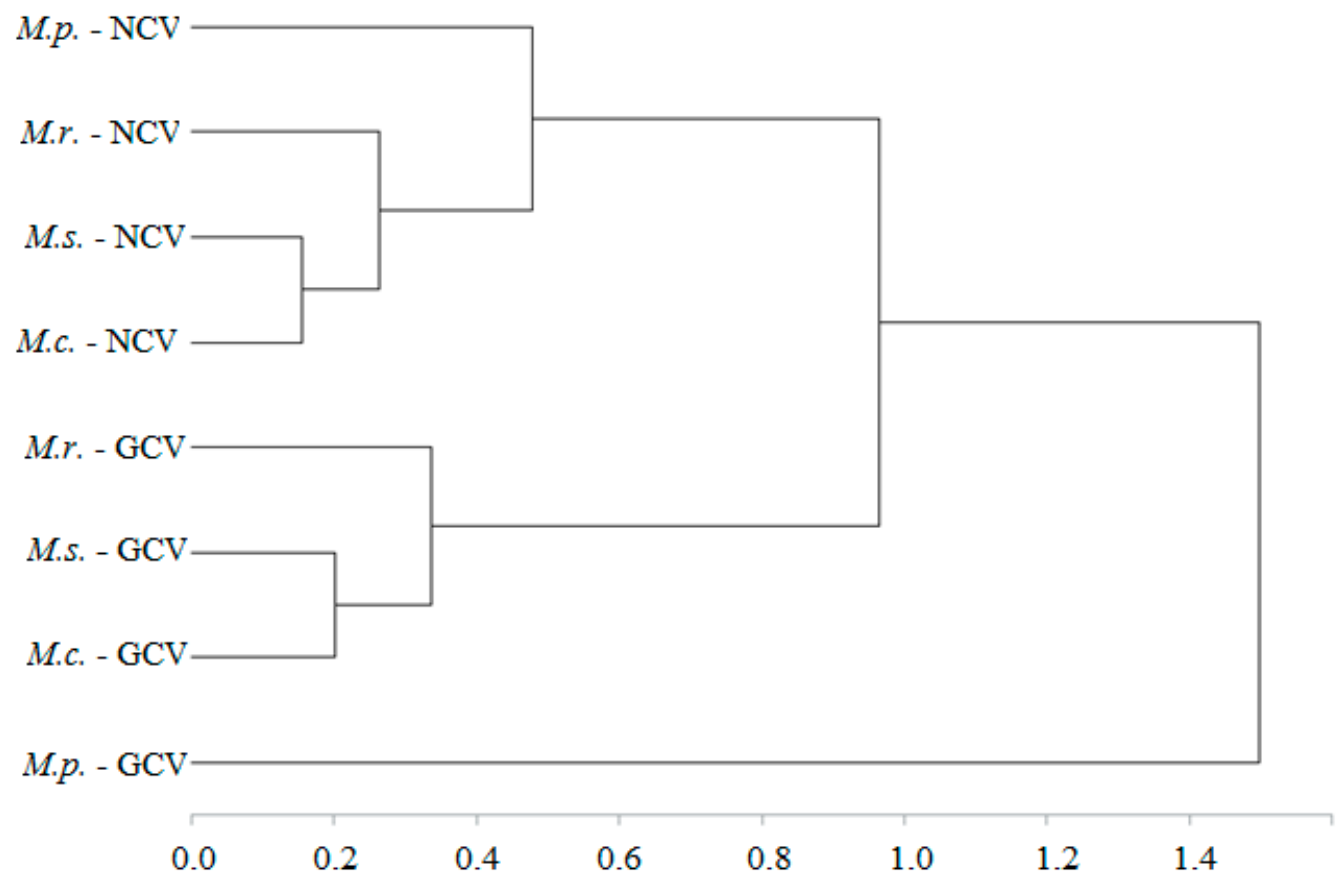

Figure 1. The dendrogram generated by the analysis clusters (GCV, NCV) in the raw materials of four species of mint: M.p.-Mentha $\times$ piperita L. var. citrata Ehrh.-_'Bergamot', M.r.-Mentha $\times$ rotundifolia L., M.s.-Mentha spicata L., M.c.-Mentha crispa L. 


\subsection{Emission Factors}

The technical and elemental analysis performed for mint was the basis for the assessment of emissions in the indicative method. Table 2 presents the results of the factors of the emissions of $\mathrm{CO}$, $\mathrm{CO}_{2}, \mathrm{NO}_{\mathrm{x}}, \mathrm{SO}_{2}$, and dust for the tested mint species.

Table 2. Results of estimated emission factors for analyzed mints $\left(\mathrm{kg} \cdot \mathrm{Mg}^{-1}\right)$.

\begin{tabular}{cccccc}
\hline Material & $\mathbf{C O}$ & $\mathbf{C O}_{\mathbf{2}}$ & $\mathbf{N O}_{\mathbf{x}}$ & $\mathbf{S O}_{\mathbf{2}}$ & $\mathbf{E}_{\text {Dust }}$ \\
\hline M. $\times$ piperita L. var. citrata Ehrh.-'Bergamot' & 57.96 & 1419.30 & 2.48 & 0.38 & 12.42 \\
M. $\times$ rotundifolia L. & 55.91 & 1369.12 & 0.82 & 0.06 & 9.14 \\
M. spicata L. & 55.21 & 1352.06 & 1.51 & 0.27 & 13.00 \\
M. crispa L. & 55.43 & 1357.32 & 1.00 & 0.15 & 10.27 \\
\hline
\end{tabular}

The analysis of the obtained CO emission factors allowed for establishing very similar values for all the materials tested. M. spicata L. had the lowest carbon dioxide emission among the tested raw materials, and it was $4.74 \%$ lower than the maximum value obtained for $M . \times$ piperita L. var. citrata Ehrh.- 'Bergamot'. This was an indication of the strong resemblance of materials used in the research. In relation to hard coal $1969 \mathrm{~kg} \cdot \mathrm{Mg}^{-1}$ [40] the emission was $31.32 \%$ for M. spicata L. and $27.92 \%$ for M. $\times$ piperita L. var. citrata Ehrh.-_'Bergamot', bearing in mind, however, that for biomass we assumed that the $\mathrm{CO}_{2}$ cycle in nature was a closed one. The highest emission of nitrogen oxides among the tested raw materials was recorded for M. spicata L., whereas the lowest was recorded for M. $\times$ rotundifolia L., and the difference was $66.94 \%$. When comparing $\mathrm{NO}_{\mathrm{x}}$ emission with hard coal $4.09 \mathrm{~kg} \cdot \mathrm{Mg}^{-1}$ [40], it was noticed that the use of biomass as a biofuel would reduce the emission of nitrogen oxides by up to $79.95 \%$. The highest emission factor among the analyzed biomass in the scope of $\mathrm{SO}_{2}$ was demonstrated for $M$. × piperita L. var. citrata Ehrh.-'Bergamot', and this value was $84.21 \%$ higher than the lowest one estimated for $M . \times$ rotundifolia L. Comparing the obtained biomass indices with the data for hard coal $5.2 \mathrm{~kg} \cdot \mathrm{Mg}^{-1}$ [40] in the scope of sulfur oxides, one can notice a much lower $\mathrm{SO}_{2}$ emission when using mint as a biofuel. Using this type of biomass, it is possible to limit the emission of sulfur compounds by up to approximately $98 \%$ in relation to fossil fuels. The dust emission factors for the examined mint species differed from each other within the range of $4.5-29 \%$. The highest emission rates were recorded for M. spicata L. and M. $\times$ piperita L. var. citrata Ehrh.-_Bergamot', whereas the lowest ones were found for $M . \times$ rotundifolia L. Contrasting the dust emission factor of the tested biomass in relation to hard coal $23.57 \mathrm{~kg} \cdot \mathrm{Mg}^{-1}$ [40], a possible reduction of emissions by $44.84 \%$ for $M$. spicata $L$. and by $61.22 \%$ for $M$. $\times$ rotundifolia L. was observed in the scope of dust when using mint as a biofuel.

Emission factors, per unit of energy (Table 3), were recorded for sulphur oxides and dust, relatively lower than those of hard coal [40]. In other cases, the estimated emission factors were at a higher level with relation to fossil fuels.

Table 3. Results of estimated emission factors for mint per unit of energy $\left(\mathrm{kg} \cdot \mathrm{GJ}^{-1}\right)$.

\begin{tabular}{cccccc}
\hline Material & $\mathbf{C O}$ & $\mathbf{C O}_{\mathbf{2}}$ & $\mathbf{N O}_{\mathbf{x}}$ & $\mathbf{S O}_{\mathbf{2}}$ & $\mathbf{E}_{\text {Dust }}$ \\
\hline M. $\times$ piperita L. var. citrata Ehrh._'Bergamot' & 3.71 & 90.96 & 0.16 & 0.02 & 0.80 \\
M. $\times$ rotundifolia L. & 3.67 & 89.84 & 0.05 & $<0.00$ & 0.60 \\
M. spicata L. & 3.73 & 91.24 & 0.10 & 0.02 & 0.88 \\
M. crispa L. & 3.69 & 90.37 & 0.07 & 0.01 & 0.68 \\
\hline
\end{tabular}

The highest emission factors calculated for energy in the scope of $\mathrm{CO}, \mathrm{CO}_{2}$, and dust were recorded for M. spicata L. It was also demonstrated that the highest $\mathrm{NO}_{\mathrm{x}}$ emission factor among the tested mints, when converted to energy, was the feature of Mentha $\times$ piperita L. var. citrata Ehrh.-'Bergamot'. However, the highest $\mathrm{SO}_{2}$ emissions, when converted to energy, were observed for $M$. $\times$ piperita L. var. citrata Ehrh.-_Bergamot' and M. spicata L. Therefore, taking into account the information above, 
it should be concluded that the least emissive fuel among the tested mints was M. $\times$ rotundifolia L., constituting the most environmentally friendly biofuel. It is a noteworthy fact that when the tested mint species are used as fuel, higher emission rates are calculated per unit of energy in the scope of $\mathrm{CO}_{2}$ in relation to hard coal $70.87 \mathrm{~kg} \cdot \mathrm{GJ}^{-1}$ [40]. However, the $\mathrm{CO}_{2}$ cycle in biomass combustion is considered to be a closed one, hence the use of mints as a fuel instead of hard coal allows the emission of this gas to be reduced in the combustion process. Increased emission in relation to hard coal [40] was recorded in the case of $\mathrm{NO}_{\mathrm{x}}$ for all tested mints (increase by $0.01-0.12 \mathrm{~kg} \cdot \mathrm{GJ}^{-1}$ ), which is undoubtedly a disadvantage of this type of material as a fuel. Increased $\mathrm{NO}_{\mathrm{x}}$ emissions contribute to acid rains or to increased corrosion of boilers. Higher $\mathrm{NO}_{\mathrm{x}}$ emissivity in relation to hard coal $0.04 \mathrm{~kg} \cdot \mathrm{GJ}^{-1}\left[{ }^{-1}\right.$ ] was also observed for all the tested materials. Reduced emissivity per unit of energy was recorded for $\mathrm{CO}$ (reduction by $0.1-0.16 \mathrm{~kg} \cdot \mathrm{GJ}^{-1}$ ), $\mathrm{SO}_{2}$ (reduction by $0.26-0.28 \mathrm{~kg} \cdot \mathrm{GJ}^{-1}$ ), and dust (reduction by $0.26-0.54 \mathrm{~kg} \cdot \mathrm{GJ}^{-1}$ ) in relation to hard coal, which testifies to a positive aspect in terms of reducing emissions when replacing fossil fuels with residues from herbal production.

\section{Discussion}

The emissions of $\mathrm{CO}_{2}$ resulting from the combustion of biomass (agricultural and silvicultural) should be considered in a special way. This is because, unlike other gas emissions, $\mathrm{CO}_{2}$ emissions are usually not included as an input for anthropogenic emissions. This is related to the theory of closed $\mathrm{CO}_{2}$ circulation, that is, cultivated biomass takes as much $\mathrm{CO}_{2}$ from the atmosphere as is emitted in the combustion process [42]. An indispensable condition for such exceptional treatment of $\mathrm{CO}_{2}$ emissions is that the amount of biomass used in the combustion process is renewed through appropriate cultivation of new biomass, which is often forgotten. In addition, it should be emphasized that the use of biomass for energy purposes also involves additional emissions associated with agrotechnical operations or transportation processes between the harvesting point and the energy conversion unit [43]. Sulfur dioxide $\left(\mathrm{SO}_{2}\right)$ is formed in the combustion process as a result of a chemical reaction between $\mathrm{S}$ contained in the fuel and oxygen $[44,45]$. A large excess of air $\left(\mathrm{O}_{2}\right)$ causes some of the sulfur to undergo oxidation to $\mathrm{SO}_{3}$. Hence, the general term $\mathrm{SO}_{\mathrm{x}}$ is used to denote the total $\mathrm{SO}_{2}$ and $\mathrm{SO}_{3}$ emission in the combustion process. It should be emphasized, however, that $90-99 \% \mathrm{~S}$ in the exhaust gas occurs in the form of $\mathrm{SO}_{2}$. It is important to remember that the emission of $\mathrm{SO}_{\mathrm{x}}$ is only slightly affected by combustion technology, device size, or combustion conditions. This is related to a high reaction rate, which does not allow for the reduction of $\mathrm{S}$ oxidation in the combustion process. This means that the emission of $\mathrm{SO}_{\mathrm{x}}$ is directly dependent on the sulfur content of the fuel. Nitrogen oxides $\mathrm{NO}_{\mathrm{x}}\left(\mathrm{NO}_{2}+\mathrm{NO}\right)$ resulting from biomass combustion processes [46] are the so-called fuel $\mathrm{NO}_{\mathrm{x}}$ [47] which is formed as a result of the release of nitrogen-containing chemical compounds from the biofuel in the presence of oxygen. Some of them transition into NOR (organic compounds containing nitrogen) at certain temperatures. The amount of $\mathrm{NO}_{\mathrm{x}}$ being formed is thus dependent on the content of $\mathrm{N}_{2}$ in the fuel. It is also important to remember thermal $\mathrm{NO}_{\mathrm{x}}$, which is formed during high-temperature combustion, that is, above $1400{ }^{\circ} \mathrm{C}$ [42]. The temperature, degree of excess air, and its dwelling time in the combustion chamber have a significant impact on the amount of thermal oxides formed. However, in the case of biomass, its combustion temperature in boilers does not exceed $800^{\circ} \mathrm{C}$. It should be emphasized that mainly $\mathrm{NO}$ (95-99\% of total $\mathrm{NO}_{\mathrm{x}}$ ) is emitted into the atmosphere, where it readily oxidizes to $\mathrm{NO}_{2}$.

The examined biomass from the herbal sector production indicated both good energy properties and low emissions potential. When we compare the examined biomass with hard coal in terms of emissions, it was noticed that emission levels were much lower for practically all the raw materials tested.

The obtained gross calorific value for the mint tested in relation to the results obtained by Parikh et al. [48] for Spire-mint is at a similar level, and the difference does not exceed $1.43 \mathrm{MJ} \cdot \mathrm{kg}^{-1}$. When we compared the obtained data relating to the net calorific value and gross calorific value, similar values were observed between M. × piperita L. var. citrata Ehrh.-'Bergamot' and wheat straw and larch needles [41]. In the case of $M . \times$ rotundifolia L., rapeseed pods were characterized by similar energy properties. M. spicata L. showed values similar to rapeseed pods [41] and peat [10], and M. crispa L. 
demonstrated resemblance to rapeseed pods [41]. One can notice much lower gross calorific values and net calorific values for the tested mint species in relation to oak leaves and apple leaves $[49,50]$. The differences reached $2.68 \mathrm{MJ} \cdot \mathrm{kg}^{-1}$ for apple leaves and $2.54 \mathrm{MJ} \cdot \mathrm{kg}^{-1}$ in relation to oak tree leaves in the case of gross calorific value, which was about $14.5 \%$.

In the case of ash content, similarities were found between $M . \times$ piperita $\mathrm{L}$. var. citrata Ehrh.-'Bergamot' and rapeseed pods, as well as M. crispa L. in relation to wheat straw [41,51,52]. The remaining species of mint differed significantly in relation to the analyzed types of biomass. In the case of $M . \times$ rotundifolia L., the difference in relation to a fossil fuel in the form of peat was $9.35 \%$, whereas for M. spicata L. it amounted to $6.29 \%$. The comparison of ash content of the tested mint with the data for Spire-mint [48] showed a 10.87\% lower ash content of the tested mint species.

Taking into consideration the content of volatile substances, both M. spicata L. and M. crispa L. have similar content in relation to wheat straw, oak leaves [49], and Spire-mint [48]. In contrast, $M . \times$ rotundifolia $\mathrm{L}$. has a similar content of volatile substances in relation to larch needles. The lowest content among the analyzed mint species was found in M. $\times$ piperita L. var. citrata Ehrh.-'Bergamot', and it was $14.85 \%$ higher than the peat fossil fuel.

Similar carbon content was found in Mentha $\times$ piperita L. var. citrata Ehrh.-'Bergamot' (the highest content among the tested plants) in relation to oak tree leaves [49], block wood [48], and Miscanthus [53]. The high carbon content translates into increased energy parameters in the form of GCV and NCV for the studied biomass. M. $\times$ rotundifolia L., on the other hand, showed a similar carbon content to larch needles [41], tall fescue ecotype, sorghum [53], M. spicata L., and M. crispa L., and have a similar carbon content to apple tree leaves [54], Sudan grass [48], reed canary grass [53], and Virginia mallow [14]. It should be noted that the tested mint has a higher carbon content also in relation to Spire-mint, and the difference in relation to M. × piperita L. var. citrata Ehrh.-'Bergamot' amounts to $13.67 \%$ [48]. Comparing the hydrogen content in the analyzed biomass with the literature data, a similar level of its content can be observed for the majority of biomass species, however, the hydrogen content is higher in relation to peat by approximately $1 \%$. The nitrogen content affects the emissions of $\mathrm{NO}_{\mathrm{x}}$ during biomass combustion. This is why very low nitrogen content for $M . \times$ rotundifolia $\mathrm{L}$. and M. crispa $\mathrm{L}$. can be noticed. Even when compared to other types of biomass, this result is similar to softwood, eucalyptus, and paddy straw [48]. The nitrogen content for M. $\times$ piperita L. var. citrata Ehrh.-'Bergamot' is comparable with rapeseed pods [41], almond prunings [48], and tall fescue ecotype [53], whereas M. spicata L. is comparable with Miscanthus [53], coconut coir, and corncob [48]. It is worth mentioning the high sulphur content obtained for M. $\times$ piperita L. var. citrata Ehrh.-'Bergamot', which can be compared with the sulphur content for peat $(0.06 \%$ difference) [10]. Furthermore, comparable sulfur content was found between M. spicata L. and oak tree leaves [49]. The lowest sulfur content was recorded in M. $\times$ rotundifolia L. and M. crispa L., which coincides with wheat straw, Virginia mallow [14], and cotton stalk [48]. Low sulfur content in biomass translates into low emissions of sulfur oxides during combustion.

When comparing the obtained emission factors with the literature data, it can be seen that the lowest emissions in the scope of $\mathrm{CO}$ and $\mathrm{CO}_{2}$ are at a similar level to $M . \times$ rotundifolia L., M. spicata L., and M. crispa L., and the obtained values coincide in particular with larch needles [41]. The factors obtained for M. × piperita L. var. citrata Ehrh.-'Bergamot' (highest emission factors) are comparable with emission factors for oak tree leaves [49] or eucalyptus globulus [2]. However, the examined biomass is not the one with the lowest emission potential. The emission and energy assessment of this raw material has not been widely discussed in the literature. It should be emphasized that the emissivity of this raw material is relatively comparable, especially in relation to biomass of agricultural, silvicultural, or horticultural origin. The use of biomass as a source of energy in individual and industrial energy generation can contribute to a significant reduction of greenhouse gas emissions, in particular when replacing even some of the fossil fuels with mint, the subject of this study.

Cultivation of herbal plants, like others, is associated with energy consumption, not only in the form of its direct carriers, such as diesel oil or electricity, but also as indirect energy, understood as 
an energy contribution to the production of tractors, machinery, fertilizers, protection products, plants, and so on [55]. In addition, the contribution of energy from fossil fuels is closely related to emissions of air and greenhouse gases $\left(\mathrm{N}_{2} \mathrm{O}, \mathrm{CO}_{2}, \mathrm{CH}_{4}\right)$ from the burning of fossil fuels by machinery and equipment used during cultivation [56]. The cultivation of herbs is also associated with $\mathrm{N}_{2} \mathrm{O}$ emissions related to the direct emissions of natural fertilizers used, or emissions related to the use of inorganic fertilizers. According to Pinstrup-Andersen [57], agriculture globally accounts for around 5\% of total energy consumed. Parton et al. [58] draw attention to economic issues forcing more and more efficient use of energy on farms, especially where energy efficiency is at the lowest level and at the same time high expenditure on energy carriers is incurred. The efficiency of energy use in agriculture is one of the conditions for sustainable agriculture. It is an important factor affecting both the amount of production costs, as well as the profits obtained from conducted operations, which allows the protection of fossil resources and reduction of air pollution. The mint obtained could be used as a boiler feed and be a source of energy for drying in herb-drying installations.

Comparing the obtained research results with the data of Cereceda-Balic et al. [59] for Pinus radiata or Nothofagus obliqua, one can notice higher levels of CO emissions for the tested materials (25\% on average) and lower levels in the scope of $\mathrm{CO}_{2}$ emissions (25\% on average), which also confirms the pro-ecological benefits of the material being studied. The emission indices obtained for $\mathrm{SO}_{2}$ are similar to those for M. $\times$ piperita L. var. citrata Ehrh.-'Bergamot' and M. spicata L. with indices for Pinus radiata, Nothofagus obliqua [59], rapeseed pods [41], and peat [10], and much lower for M. $\times$ rotundifolia L., M. crispa L. (60\% on average) with wheat straw, larch needles [41], Pinus radiata, and Nothofagus obliqua. The reduction of $\mathrm{SO}_{2}$ emission by $60 \%$ when using $M . \times$ rotundifolia $\mathrm{L}$. and $M$. crispa L. compared to the materials above indicates that this biofuel exhibits low emissivity and is environmentally friendly. The tested biomass is characterized by high $\mathrm{NO}_{x}$ emission rates, which is consistent with the emission levels for wheat straw pellets, sunflower pellets, corn stalk pellets, and wood pellets obtained by Krugly et al. [51], which is undoubtedly a disadvantage of these biofuels, and excessive use of this type of biomass can contribute to the formation of acid rain.

The presented emission factors indicate a reduction of $29-32 \%$ for $\mathrm{CO}, 28-31 \%$ for $\mathrm{CO}_{2}, 40-80 \%$ for $\mathrm{NOx}, 92-98 \%$ for $\mathrm{SO}_{2}$, and $45-61 \%$ for dust, depending on the type of the biomass used in relation to hard coal. Compared to other types of biomass, an average $25 \%$ higher CO emission factor and $25 \%$ lower $\mathrm{CO}_{2}$ emission factor for the tested objects compared to Pinus radiata or Nothofagus obliqua was determined. $\mathrm{SO}_{2}$ emission factors were shown to be $60 \%$ lower when using $M . \times$ rotundifolia L. and M. crispa L. compared to wheat straw, larch needles, Pinus radiata, and Nothofagus obliqua. Comparing $\mathrm{NO}_{x}$ emission factors, similar values of emission factors for wheat straw pellets, sunflower stalk pellets, corn stalk pellets, and wood pellets were noted, whereas the largest differences were observed in relation to larch needles for M. crispa L. (average reduction of $31 \%$ ) and M. $\times$ rotundifolia L. (reduction by an average of $25 \%$ ). The estimated dust emission factors for the tested mint were at a high level due to the high ash content. However, the application of the tested material allowed for a reduction of the emission factors in relation to oak tree leaves (biomass with a high dust emission factor) by $46 \%$ for M. spicata L., 44\% for M. × piperita L. Ehrh.-'Bergamot', 37\% for M. crispa L., and 32\% for M. $\times$ rotundifolia $\mathrm{L}$. It should be noted that the utilization of horticulture biomass in the form of mint as a fuel significantly reduces the emissions of harmful compounds to the natural environment. Hence, the possibility of using residual waste from the production of mint in the renewable energy sector gives real environmental benefits, which is very important for the environment.

\section{Conclusions}

The examined biomass in the form of various species of mint exhibited a significant energy yield potential, found also in the context of other biomass types, be it of agricultural, silvicultural, or peat origin. The obtained results allow for the drawing of a conclusion that residual waste from mint production may contribute to increasing energy diversification in the fuel and energy balance of the economy and constitute a significant biofuel in the renewable energy sector. Assuming that the annual 
cultivation size for the tested mint in the EU is 17,520 ha and in Poland 6570 ha $(21.9 \%$ in general herb cultivation $[18,19]$ ), the energy potential for mint crops per year is $531,556.8 \mathrm{GJ} \cdot \mathrm{a}^{-1}$ for the European Union, and 199,333.8 GJ.a ${ }^{-1}$ for Poland for the tested mints' average net calorific value of $15.17 \mathrm{MJ} \cdot \mathrm{kg}^{-1}$. Energy potential per crop area of mint is on average $30.34 \mathrm{GJ} \cdot \mathrm{ha}^{-1}$. Such a large potential contained in the residues from mint cultivation can be used to dry herbs in solid fuel dryer systems. By using bio-waste as a biofuel in drying boilers, the amount of hard coal used as an energy carrier could be reduced in about $75 \mathrm{~kg}$ per day using $20 \mathrm{~kW}$ boilers. Even reducing the partial use of fossil fuels for bio-waste would also contribute to the ecological effect by reducing emissions to the environment associated with the use of biofuels.

The highest net calorific value was recorded for M. $\times$ piperita L. var. citrata Ehrh.-_Bergamot' 15.60 MJ. $\mathrm{kg}^{-1}$, followed by M. $\times$ rotundifolia L., M. crispa L., and M. spicata L. (14.82 MJ.kg-1). The research demonstrates that this distribution is mainly related to the content of carbon in the biomass. In addition, the studied biomass was characterized by the FR at a very similar level $(0.23-0.27)$, which indicated a significant similarity between the fuels studied.

The research demonstrated that the analyzed biomass was characterized by ash content in the range of $7.23 \%$ for $M$. $\times$ rotundifolia $\mathrm{L}$. up to $10.29 \%$ for $M$. spicata $\mathrm{L}$. Such ballast content is at a level similar to the biomass of agricultural origin and slightly higher than for wood biomass. The obtained levels of ash content allowed for a positive assessment of the examined biomass in the context of its application for energy generation purposes, and also for defining mint as a low-emissions fuel with significant energy potential. Compared to the ash content for hard coal [60], the use of mint as biofuel allows for the reduction of the amount of ash obtained by 4.91-7.97\% depending on the type of mint.

The estimated emission factors for the tested biomass showed lower emissions of $29-32 \% \mathrm{CO}$, $28-31 \% \mathrm{CO}_{2}, 40-80 \% \mathrm{NO}_{\mathrm{x}}, 92-98 \% \mathrm{SO}_{2}$, and $45-61 \%$ dust compared to hard coal. It allows for qualifying mint as a low-emission fuel with a significant application potential, meeting the assumptions of sustainable development of the energy sector.

Author Contributions: Conceptualization, G.M. and A.N.; methodology, G.M. and A.N.; validation, G.M.; formal analysis, G.M.; investigation, G.M. and A.N.; resources, A.N., K.K. and S.B.; writing-original draft preparation, G.M., A.N. and K.K.; writing-review and editing, G.M., A.N., K.K. and S.B.; supervision, G.M. and A.N. All authors have read and agreed to the published version of the manuscript.

Funding: The work was funded from the statutory activity of the University of Life Sciences in Lublin.

Conflicts of Interest: The authors declare no conflict of interest.

\section{References}

1. Kraszkiewicz, A.; Stryjecka, M.; Nowosad, N.; Kocira, S. Burden for the environment by the products of pellets from plant biomass incineration in low-power heating devices. Rocz. Ochr. Srodowiska 2018, 20, 1269-1285.

2. Mateos, E.; Ormaetxea, L. Sustainable Renewable Energy by Means of Using Residual Forest Biomass. Energies 2019, 12, 13. [CrossRef]

3. Kowalczyk-Juśko, A. The influence of the ash from the biomass on the power boiler pollution. J. Ecol. Eng. 2017, 18, 200-204. [CrossRef]

4. Nádudvari, Á.; Fabiańska, M.J.; Marynowski, L.; Kozielska, B.; Konieczyński, J.; Smółka-Danielowska, D.; Ćmiel, S. Distribution of coal and coal combustion related organic pollutants in the environment of the Upper Silesian Industrial Region. Sci. Total Environ. 2018, 628, 1462-1488. [CrossRef]

5. Ozgen, S.; Caserini, S.; Galante, S.; Giugliano, M.; Angelino, E.; Marongiu, A.; Hugony, F.; Migliavacca, G.; Morreale, C. Emission factors from small scale appliances burning wood and pellets. Atmos. Environ. 2014, 94, 144-153. [CrossRef]

6. Villeneuve, J.; Palacios, J.H.; Savoie, P.; Godbout, S. A critical review of emission standards and regulations regarding biomass combustion in small scale units (<3 MW). Bioresour. Technol. 2012,111,1-11. 
7. Zhang, R.; Lei, K.; Bu, Q.Y.; Cao, J.; Liu, D. Effects of alkali and alkaline earth metal species on the combustion characteristics of single particles from pine sawdust and bituminous coal. Bioresour. Technol. 2018, 268, 278-285. [CrossRef]

8. Liang, F.; Wang, R.; Jiang, C.; Yang, X.; Zhang, T.; Hu, W.; Mi, B.; Liu, Z. Investigating co-combustion characteristics of bamboo and wood. Bioresour. Technol. 2017, 243, 556-565. [CrossRef]

9. Ullah, H.; Liu, G.; Yousaf, B.; Ali, M.U.; Abbas, Q.; Zhou, C. Combustion characteristics and retention-emission of selenium during co-firing of torrefied biomass and its blends with high ash coal. Bioresour. Technol. 2017, 245, 73-80. [CrossRef]

10. Maj, G. Analysis of Energy Properties and Emissions Factors of Selected Plant Biomass and Peat. In Proceedings of the IX International Scientific Symposium Farm Machinery and Processes Management in Sustainable Agriculture: Symposium Proceedings, Lublin, Poland, 22-24 November 2017; pp. 222-227.

11. Konieczyński, J.; Komosiński, B.; Cieślik, E.; Konieczny, T.; Mathews, B.; Rachwa, T.; Rzońca, G. Research into properties of dust from domestic central heating boiler fired with coal and solid biofuels. Arch. Environ. Prot. 2017, 43, 20-27. [CrossRef]

12. Czop, M.; Kajda-Szcześniak, M. Environmental impact of straw based fuel combustion. Arch. Environ. Prot. 2013, 39, 71-80. [CrossRef]

13. Gürkan, G.A.K.; Demirel, B.; Selvi, K.Ç.; Kabas, Ö.; Vladut, V. Evaluation of waste biomass from oat cultivation for energy. Acta Tech. Corviniensis-Bull. Eng. 2016, 9, 163.

14. Szyszlak-Barglowicz, J.; Zajac, G.; Slowik, T. Research on Emissions from Combustion of Pellets in Agro Biomass Low Power Boiler. Rocz. Ochr. Srodowiska 2017, 19, 715-730.

15. Fernandes, E.R.K.; Marangoni, C.; Souza, O.; Sellin, N. Thermochemical characterization of banana leaves as a potential energy source. Energy Convers. Manag. 2013, 75, 603-608. [CrossRef]

16. Kimming, M.; Sundberg, C.; Nordberg, A.A.; Baky, A.; Bernesson, S.; Hansson, P.-A. Replacing fossil energy for organic milk production-potential biomass sources and greenhouse gas emission reductions. J. Clean. Prod. 2015, 106, 400-407. [CrossRef]

17. Obernberger, I.; Brunner, T.; Mandl, C.; Kerschbaum, M.; Svetlik, T. Strategies and technologies towards zero emission biomass combustion by primary measures. Energy Procedia 2017, 120, 681-688. [CrossRef]

18. Jambor, J. Uprawa ziół i przetwórstwo zielarskie w Polsce-stan obecny i perspektywy rozwoju. In Proceedings of the 12th International Congress of Polish Herbal Committee, Poznań, Poland, 24-25 May 2007; Volume 53, pp. 25-26.

19. Najda, A. Ontogenetic Variability of Mint (Mentha Species) a Factor Conditioning the Content of Bioactive Components in the Raw Material; University of Life Sciences in Lublin: Lublin, Poland, 2017.

20. Olewnicki, D.; Jablonska, L.; Orlinski, P.; Gontar, L. Changes in Polish domestic production of herbal plants and in selected types of enterprises that process herbal plants in the context of the global increase in demand for these products. Sci. J. SGGW. Probl. World Agric. 2015, 15, 68-76.

21. Najda, A. Chemical composition and antioxidant activity of extracts from Mentha $\times$ piperita L. Prog. Phytother. 2017, 18, 251-258.

22. Obidziński, S. Pelletization process of postproduction plant waste. Int. Agrophys. 2012, 26, $279-284$. [CrossRef]

23. Żabiński, A.; Sadowska, U.; Wcisło, G. Options of use of waste biomass from herbal produc-tion for energy purposes. Agric. Eng. 2015, 19, 139-145.

24. Stankiewicz, D. Possibilities of using agricultural raw materials for energy production in Poland. Stud. BAS 2010, 21, 237-266.

25. Obidzinski, S. Profile of water activity and geometric parameters of lemon balm wastes in the aspect of their utilisation as an addition to fodders. Acta Agrophys. 2013, 20, 113-124.

26. Chan, E.W.C.; Lim, Y.Y.; Wong, S.K.; Lim, K.K.; Tan, S.P.; Lianto, F.S.; Yong, M.Y. Effects of different drying methods on the antioxidant properties of leaves and tea of ginger species. Food Chem. 2009, 113, 166-172. [CrossRef]

27. Karwowska, K.; Przybył, J. Drying and Processing of Herbs; SGGW Publishing: Warszawa, Poland, 2005; ISBN 83-7244-621-0.

28. Gruszczyk, M.; Kołodziej, B.; Król, B.; Kucharski, W.A.; Mordalski, R.; Najda, A.; Nurzyńska-Wierdak, R.; Seidler-Łożykowska, K.; Sugier, D.; Wiśniewski, J.; et al. Herb Cultivation Guide for Growers, 2nd ed.; Powszechne Wydawnictwo Rolnicze i Leśne: Warszawa, Poland, 2018; ISBN 978-83-09-01110-1. 
29. Costa, A.G.; Bertolucci, S.K.V.; Chagas, J.H.; Ferraz, E.O.; Pinto, J.E.B.P. Biomass production, yield and chemical composition of peppermint essential oil using different organic fertilizer sources. Ciência e Agrotecnologia 2013, 37, 202-210. [CrossRef]

30. Santos, V.M.C.S.; Pinto, M.A.S.; Bizzo, H.R.; Deschamps, C. Seasonal variation of vegetative growth, essential oil yield and composition of menthol mint genotypes at southern Brazil. Embrapa Agroindústria de Alimentos-Artigo em periódico indexado (ALICE) 2012, 28, 790-798.

31. Németh, É.; Szabó, K.; Raihárt, P.; Popp, U. Die wirkung der caliumversorgung auf die production und drogenqualitát von Minzen. Z Arznei-Gevurzpfla 2012, 17, 158-164.

32. Mahmoodabad, H.A.; Parchin, R.A.; Hokmalipoor, S.; Shaban, M. Changes in yield and growth of green Mint (Mentha spicata L.) Under foliar application of urea and soil application of vermicompost. Int. J. Adv. Biol. Biomed. Res. 2014, 2, 2072-2076.

33. Kołodziej, B. The effect of the term of plantation establishment, rejuvenating ploughing and Asahi SL application in peppermint culture. Ann. UMCS Agric. 2008, 63. [CrossRef]

34. ISO. EN-ISO 18122:2016-01 Solid Biofuels. Determination of Ash Content 2016; ISO: Geneva, Switzerland, 2016.

35. ISO. EN-ISO 18123:2016-01 Solid Fuels—Determination of Volatile Content by Gravimetric Method; ISO: Geneva, Switzerland, 2016.

36. ISO. EN-ISO 18134-3:2015 Solid Biofuels-Determination of Moisture Content-Oven Dry Method-Part 3: Moisture in General Analysis Sample; ISO: Geneva, Switzerland, 2015.

37. ISO. EN-ISO 1928:2009 Solid Mineral Fuels-Determination of Gross Calorific Value by the Bomb Calorimetric Method and Calculation of Net Calorific Value; ISO: Geneva, Switzerland, 2010.

38. ISO. EN-ISO 16948:2015-07 Solid Biofuels_Determination of Total Content of Carbon, Hydrogen and Nitrogen; ISO: Geneva, Switzerland, 2015.

39. ISO. ISO 16994:2016 Solid Biofuels-Determination of Total Content of Sulphur and Chlorine; ISO: Geneva, Switzerland, 2016.

40. Borycka, B. Commodity Study on Food and Energy Utilization of Rich-Food Waste of the Fruit and Vegetables Industry; Radom University of Technology: Radom, Poland, 2008.

41. Maj, G. Emission factors and energy properties of Agro and forest biomass in aspect of sustainability of energy sector. Energies 2018, 11, 1516. [CrossRef]

42. Sahu, S.G.; Chakraborty, N.; Sarkar, P. Coal-biomass co-combustion: An overview. Renew. Sustain. Energy Rev. 2014, 39, 575-586. [CrossRef]

43. Gustavsson, L.; Johansson, B.; Svenningsson, P. Reducing $\mathrm{CO}_{2}$ emissions by substituting biomass for fossil fuels. Energy 2015, 20, 1097-1113. [CrossRef]

44. Magdziarz, A.; Wilk, M. Thermal characteristics of the combustion process of biomass and sewage sludge. J. Therm. Anal. Calorim. 2013, 114, 519-529. [CrossRef]

45. Modaresi, Z.K.; Karimi, G.; Mowla, D. Study of co-combustion of dried sewage sludge with coke: Thermogravimetric assessment and gaseous emissions. J. Environ. Chem. Eng. 2019, 7, 102871. [CrossRef]

46. Jenkins, B.M.; Baxter, L.L.; Miles, T.R., Jr.; Miles, T.R. Combustion properties of biomass. Fuel Process. Technol. 1998, 54, 17-46. [CrossRef]

47. Osman, A.I. Mass spectrometry study of lignocellulosic biomass combustion and pyrolysis with NOx removal. Renew. Energy 2020, 146, 484-496. [CrossRef]

48. Parikh, J.; Channiwala, S.A.; Ghosal, G.K. A correlation for calculating HHV from proximate analysis of solid fuels. Fuel 2005, 84, 487-494. [CrossRef]

49. Maj, G.; Piekut, J. Comparing Emission Factors and Physicochemical Properties of Waste-Biomass Leaves of Selected Species of Trees. Pol. J. Environ. Stud. 2018, 27, 2155-2162. [CrossRef]

50. García, R.; Pizarro, C.; Lavín, A.G.; Bueno, J.L. Biomass sources for thermal conversion. Techno-economical overview. Fuel 2017, 195, 182-189. [CrossRef]

51. Krugly, E.; Martuzevicius, D.; Puida, E.; Buinevicius, K.; Stasiulaitiene, I.; Radziuniene, I.; Minikauskas, A.; Kliucininkas, L. Characterization of gaseous-and particle-phase emissions from the combustion of biomass-residue-derived fuels in a small residential boiler. Energy Fuels 2014, 28, 5057-5066. [CrossRef]

52. Williams, A.; Jones, J.M.; Ma, L.; Pourkashanian, M. Pollutants from the combustion of solid biomass fuels. Prog. Energy Combust. Sci. 2012, 38, 113-137. [CrossRef]

53. Lalak, J.; Martyniak, D.; Kasprzycka, A.; Żurek, G.; Moron, W.; Chmielewska, M.; Wiącek, D.; Tys, J. Comparison of selected parameters of biomass and coal. Int. Agrophys. 2016, 30, 475-482. [CrossRef] 
54. García, R.; Pizarro, C.; Lavín, A.G.; Bueno, J.L. Characterization of Spanish biomass wastes for energy use. Bioresour. Technol. 2012, 103, 249-258. [CrossRef] [PubMed]

55. Hülsbergen, K.-J.; Feil, B.; Biermann, S.; Rathke, G.-W.; Kalk, W.-D.; Diepenbrock, W. A method of energy balancing in crop production and its application in a long-term fertilizer trial. Agric. Ecosyst. Environ. 2001, 86, 303-321. [CrossRef]

56. Erdal, G.; Esengün, K.; Erdal, H.; Gündüz, O. Energy use and economical analysis of sugar beet production in Tokat province of Turkey. Energy 2007, 32, 35-41. [CrossRef]

57. Pinstrup Andersen, P. Towards ecologically sustainable world food production. Ind. Environ. Fr. 1999, 22, 10-13.

58. Parton, W.J.; Del Grosso, S.J.; Marx, E.; Swan, A.L. Agriculture's role in cutting greenhouse gas emissions. Issues Sci. Technol. 2011, 27, 29-32.

59. Cereceda-Balic, F.; Toledo, M.; Vidal, V.; Guerrero, F.; Diaz-Robles, L.A.; Petit-Breuilh, X.; Lapuerta, M. Emission factors for PM2.5, $\mathrm{CO}, \mathrm{CO}_{2}, \mathrm{NO}_{\mathrm{x}}, \mathrm{SO}_{2}$ and particle size distributions from the combustion of wood species using a new controlled combustion chamber 3CE. Sci. Total Environ. 2017, 584, 901-910. [CrossRef]

60. Vamvuka, D.; Kakaras, E. Ash properties and environmental impact of various biomass and coal fuels and their blends. Fuel Process. Technol. 2011, 92, 570-581. [CrossRef]

(C) 2019 by the authors. Licensee MDPI, Basel, Switzerland. This article is an open access article distributed under the terms and conditions of the Creative Commons Attribution (CC BY) license (http://creativecommons.org/licenses/by/4.0/). 